\title{
Pictures and Power: The Visual Prints of Frans Hogenberg
}

\author{
Ramon Voges
}

On 19 February 1582, François-Hercule de Valois was inaugurated as the new duke of Brabant outside the city walls of Antwerp. ${ }^{1}$ Subsequently, his ceremonial entry into the city took place. ${ }^{2}$ The summer before, the States General of the Netherlands had declared that the previous duke of Brabant and sovereign of the Low Countries, Philip II of Spain, had forfeited his right to rule. ${ }^{3}$ The States had justified Philip's deposition in the Plakkaat van Verlatinge by claiming he had violated the old liberties, privileges and rights of the provinces. In constructing this argument, the privileges of the duchy of Brabant from the year $135^{6}$ played a central role. ${ }^{4}$ These privileges were called Joyeuse Entrée after the solemn entry ritual during which the new ruler had to swear to uphold them. The charter provided that a ruler could be deprived of his right to power if he acted contrary to them. The States General had finally decided to offer François-Hercule, brother to the king of France and already the duke of Anjou and Alençon, to become their new sovereign. ${ }^{5}$ After nearly one hundred years, the Low Countries were once again ruled by a prince of the house Valois, the old rivals of the Habsburg dynasty. ${ }^{6}$

1 See Peter Arnade, Beggars, Iconoclasts, and Civic Patriots. The Political Culture of the Dutch Revolt (Ithaca/London: Cornell University Press, 2008), pp. 304-311. Some parts of this paper were first presented at the symposion of the Rijksmuseum in Antwerp in 2017, some at the trilateral conference Villa Vigoni, Italy, in 2018. For this volume they were extended and elaborated. I wish to thank all commentators.

2 For these rituals, consult Margit Thøfner, A Common Art: Urban Ceremonial in Antwerp and Brussels during and after the Dutch Revolt (Zwolle: Waanders, 2007), pp. 51-57.

3 For a critical edition of the Plakkaat, consult M.E.H.N. Mout (ed.), Plakkaat van Verlatinge 1581. Faksimile-uitgave van de originele druk: 'Charles Silvius, Ghesworen Drucker der Staten 's Landts van Hollandt'. Inleiding, transcriptie en vertaling in hedendaags Nederlands (The Hague: Staatsuitgeverij, 1979).

4 Pieter A.M. Geurts, De Nederlandse Opstand in de Pamfletten 1566-1584 (Utrecht: H\&S, 1983), pp. 149-151.

5 For the negotiations with Anjou consult Mack P. Holt, The Duke of Anjou and the Political Struggle During the War of Religion (Cambridge: Cambridge University Press, 1986), pp. 128-140.

6 Holt, The Duke of Anjou, pp. 166-169. 
François-Hercule, or Anjou, as most of his contemporaries simply called him, was obliged upon his first official and peaceful entry into a city to swear to respect the rights and liberties that Philip was supposed to have broken. The deposition of the old sovereign and the founding of a new polity took place in the guise of old privileges, traditions and rituals. ${ }^{7}$ It did not last long, as Anjou lost no time alienating large parts of the political elite. Just one year after his inauguration, dissatisfied with his limited power, Anjou attempted a coup d'état in Antwerp. He failed utterly. The violent episode in Antwerp became known as the French Fury, and Anjou fled the Low Countries in June 1583.

Ancient privileges and rituals had been at the centre of these conflicts ever since they began, yet in the last decades of the sixteenth century, something had changed fundamentally. For the first time in the history of the Low Countries, visual prints played a vital role in these struggles for power and authority. ${ }^{8}$ As Alastair Duke has pointed out, prints conveyed not only news on the ongoing political and military conflicts, they also often advertised the arguments of the warring parties. ${ }^{9}$ Print in general, with or without visual elements, was used on both sides to win over the public or to strengthen their support. Even by buying a pamphlet, contemporaries could underline their affiliation with the political viewpoint expressed in it as though pinning on a corresponding badge. ${ }^{10}$ Print was especially crucial when and where direct face-to-face communication was too dangerous." That is why the rebels made use of printed tracts, pamphlets and news sheets as a means of substituting direct interactions. While it took the Habsburg regime quite a long time to adjust to these new developments,

7 Arnade, Beggars, Iconoclasts and Civic Patriots, p. 311; also Anne-Laure van Bruaene, 'Spectacle and Spin for a Spurned Prince. Civic Strategies in the Entry Ceremonies of the Duke of Anjou in Antwerp, Bruges and Ghent (1582)', Journal of Early Modern History, 11 (2007), pp. 262-284; Thøfner, A Common Art, pp. 125-141; as well as Emily J. Peters, 'Printing Ritual: The Performance of Community in Christopher Plantin's La Joyeuse \& Magnifique Entrée de Monseigneur Francoys ... d'Anjou', Renaissance Quarterly, 61:2 (2008), pp. 370-413.

8 Monica Stensland, Habsburg Communication in the Dutch Revolt (Amsterdam: Amsterdam University Press, 2012); Alastair C. Duke, 'Dissident Propaganda and Political Organization at the Outbreak of the Revolt of the Netherlands', in Judith Pollmann and Andrew Spicer (eds.), Dissident Identities in the Early Modern Low Countries (Farnham: Ashgate, 2009), pp. 137-156; Andrew Pettegree, The Book in the Renaissance (New Haven/London: Yale University Press, 2010), pp. 214-218.

$9 \quad$ Alastair C. Duke, 'Posters, Pamphlets and Prints: The Ways and Means of Disseminating Dissident Opinions on the Eve of the Dutch Revolt', in Pollmann and Spicer (eds.), Dissident Identities, pp. 157-177.

10 See Andrew Pettegree, Reformation and the Culture of Persuasion (Cambridge: Cambridge University Press, 2005), p. 215.

11 See Stensland, Habsburg Communication, p. 155. 
recent research considers the new media to have been one of the driving forces of the Dutch Revolt.12 Anjou's inauguration as well as many other rituals have already been examined by historians in this context. ${ }^{13} \mathrm{By}$ focusing on the visual representations of these rituals, this essay will analyse an aspect of the media war that is less studied: how visual images affected political discourse.

In the following, I will analyse how the visual reports of Frans Hogenberg represented three different events. As accounts of political, religious and military conflicts, I argue, Hogenberg's prints wielded power themselves and played a crucial role in the political communication on the Dutch Revolt. By emphasising, criticising or even refuting claims to power, they acted as power brokers as well. To develop my argument, I will briefly describe the corpus of the Hogenberg prints and the circumstances under which they were produced. Then I will analyse three of Hogenberg's prints concerned with events that contemporaries considered to be crucial moments in the Dutch Revolt and the Eighty Years War. ${ }^{14}$

\section{Hogenberg's Visual Reports}

The cartographer, etcher and publisher Frans Hogenberg left the Low Countries in the 156os and settled in the Free Imperial City of Cologne at the end of the decade..$^{15}$ At that time, Cologne was a centre of the European book market not only for Catholic pastoral works and theology but also for irenicism. ${ }^{16}$ While the Imperial city succeeded in remaining neutral in the ongoing conflicts in the neighbouring Low Countries, Hogenberg managed to build up a successful and flourishing workshop. ${ }^{17} \mathrm{He}$ contributed to most of the maps in Abraham Ortelius's Theatrum Orbis Terrarum and made a fortune with a complementary project: the Civitates Orbis Terrarum, an atlas presenting views and maps

12 See e.g. Arnade, Beggars, Iconoclasts and Civic Patriots.

13 See Van Bruaene, 'Spectacle and Spin for a Spurned Prince'.

14 For an analysis of all of the Hogenberg prints, see Ramon Voges, Das Auge der Geschichte. Der Aufstand der Niederlande und die Französischen Religionskriege im Spiegel der Bildberichte Franz Hogenbergs (ca. 1560-1610) (Leiden: Brill, 2019).

15 Voges, Das Auge der Geschichte, pp. 38-53.

16 Pettegree, The Book in the Renaissance, p. 257; Wilfried Enderle, 'Die Buchdrucker der Reichsstadt Köln und die katholische Publizistik zwischen 1555 und 1648', in Georg Mölich and Gerd Schwerhoff (eds.), Köln als Kommunikationszentrum. Studien zur frühneuzeitlichen Stadtgeschichte (Cologne: DuMont, 2000), pp. 167-182.

17 Hans-Wolfgang Bergerhausen, Köln in einem eisernen Zeitalter 16ı-1686 (Cologne: Greven, 2010), p. 10. 
of all the major cities in the world. ${ }^{18}$ Its first edition appeared on the book market in $1572 .{ }^{19}$ Apart from Hogenberg, his co-worker Simon van der Neuvel, or Novellanus, and the Cologne scholar and cleric Georg Braun were involved in its publication. ${ }^{20}$ Throughout his career, Hogenberg showed no aversion to working together with partners across the widening confessional divides. Even though Hogenberg's attendance of some forbidden underground meetings of Lutherans had caused him problems with the city authorities of Cologne, he belonged to the very few immigrants from the Low Countries who were allowed to stay in the metropolis. After his death in 1590, his son Abraham took over the workshop and continued his father's work.

In 1570, a decade before Anjou swore the oath in Antwerp, Hogenberg had published three series of visual reports on the Conquest of Tunis by Charles $\mathrm{v}$, the French Wars of Religion and the first years of the Dutch Revolt. ${ }^{21} \mathrm{He}$ continued to produce broadsheets depicting recent events, most of them concerning political and military conflicts in an area reaching from the Ottoman Empire to the British Isles. However, Hogenberg devoted about three quarters of his visual reports to the French Wars of Religion and the Dutch Revolt. ${ }^{22}$ In addition to maps and city plans, Hogenberg's workshop published about 250 broadsheets during Frans's lifetime and another 170 under the guidance of his son Abraham. From 1570 to 1631, the workshop released approximately 420 visual reports. They were sold both as single broadsheets covering recent events and, later, as compiled series. ${ }^{23}$

Hogenberg's visual reports could be bought in his Cologne workshop, but, like other broadsheets, they were also offered for sale on the Frankfurt book

18 Modern editions of the Civitates: Raleigh Ashlin Skelton and A.O. Vietor (eds.), Civitates Orbis Terrarum. 1572-1618. In Six Parts (Amsterdam: Theatrum Orbis Terrarum, 1965); a newer edition is available Stephan Füssel (ed.), Städte der Welt - Civitates Orbis Terrarum (Cologne: Taschen, 2008).

19 Georg Braun and Frans Hogenberg, Civitates orbis terrarum (Cologne: Philips Galle and Frans Hogenberg, 1572) UsTC 622654.

20 Raleigh Ashlin Skelton, 'Introduction', in Skelton and Vietor (eds.), Civitates Orbis Terrarum, I, pp. viii-xiv.

21 Fritz Hellwig (ed.), Franz Hogenberg -Abraham Hogenberg. Geschichtsblätter (Nördlingen: Verlag Dr. Alfons Uhl, 1983), pp. 1-10, pp. 18-51 and pp. 106-130.

22 For an overview Fritz Hellwig, 'Einführung', in Hellwig (ed.), Geschichtsblätter, pp. 32-43.

23 This becomes evident by studying the catalogues in Bernhard Fabian (ed.), Die Messkataloge Georg Willers. Herbstmesse 1564 bis Herbstmesse 1573 (Hildesheim/New York: Olms, 1972), p. 366, 443, 506 and 531f.; additionally several different editions of the prints have survived, so that one can clearly distinguish between single broadsheets and different series, see Ursula Mielke and Ger Luijten (eds.), Frans Hogenberg, Broadsheets. Vol. 2: Text (Ouderkerk aan den IJssel: Sound \& Vision, 2009). 
fair and touted by itinerant tradesmen. ${ }^{24}$ What distinguishes the Hogenberg prints from the vast majority of other contemporary accounts of the recent past is the emphasis they put on the visual depiction of the portrayed events. ${ }^{25}$ Hogenberg had decided to etch the broadsheets. Since the manufacturing process of broadsheets with etched images was more complicated and time consuming than that of handwritten letters or printed news sheets, they could not be published as quickly as other news media. ${ }^{26}$ Evidently, therefore, people did not buy the Hogenberg reports because they were looking for first-hand information. Sources like the family chronicle by the Cologne magistrate Hermann Weinsberg suggest that he purchased them instead because they offered the impression of viewing the actual events. ${ }^{27}$ People like Weinsberg spent on average 2 Albus (the hourly wage of a craftsman in a free Imperial city) per sheet as they hoped to get a reliable and accurate depiction of the occurrences. ${ }^{28}$

Since political communication in the late sixteenth century relied heavily on direct face-to-face situations like ceremonies, rituals, plays or processions, Hogenberg's visual reports provided an opportunity not only to capture these ephemeral events, but also to comment on them from a distanced point of view. This raises the question of how Hogenberg and his co-workers represented acts of political communication in their visual prints.

\section{Judicial Murder}

To eradicate heresy, to break the opposition of the nobility and to restore order, Philip II pursued at first a strategy of exemplary punishments. ${ }^{29}$ For this task he sent as his executioner Don Fernando Álvarez de Toledo, the duke of Alba, to the Netherlands. Two prominent victims of this strategy were Lamoral, the

24 The first evidence concerning the Frankfurt book fair is Die Messkataloge Georg Willers, p. 366 .

25 For the following see also Ramon Voges, 'Augenzeugenschaft und Evidenz. Die Bildberichte Franz und Abraham Hogenbergs als visuelle Historiographie', in Sybille Krämer, Sibylle Schmidt, and Ramon Voges (eds.), Politik der Zeugenschaft. Zur Kritik einer Wissenspraxis (Bielefeld: transcript, 2011), pp. 159-181.

26 For the printing process see Ad Stijnman, Engraving and Etching 1400-2000. A History of the Development of Manual Intaglio Printmaking Processes (Houten: Hes \& de Graaf, 2012).

27 Manfred Groten (ed.), Gedenkboich. Liber Senectutis (Institut für geschichtliche Landeskunde der Rheinlande der Universität Bonn, n.d.), p. 589. Available online http://www .weinsberg.uni-bonn.de/.

28 Voges, Das Auge der Geschichte, p. 86, pp. 319-336.

29 Stensland, Habsburg Communication, pp. 30-32. 


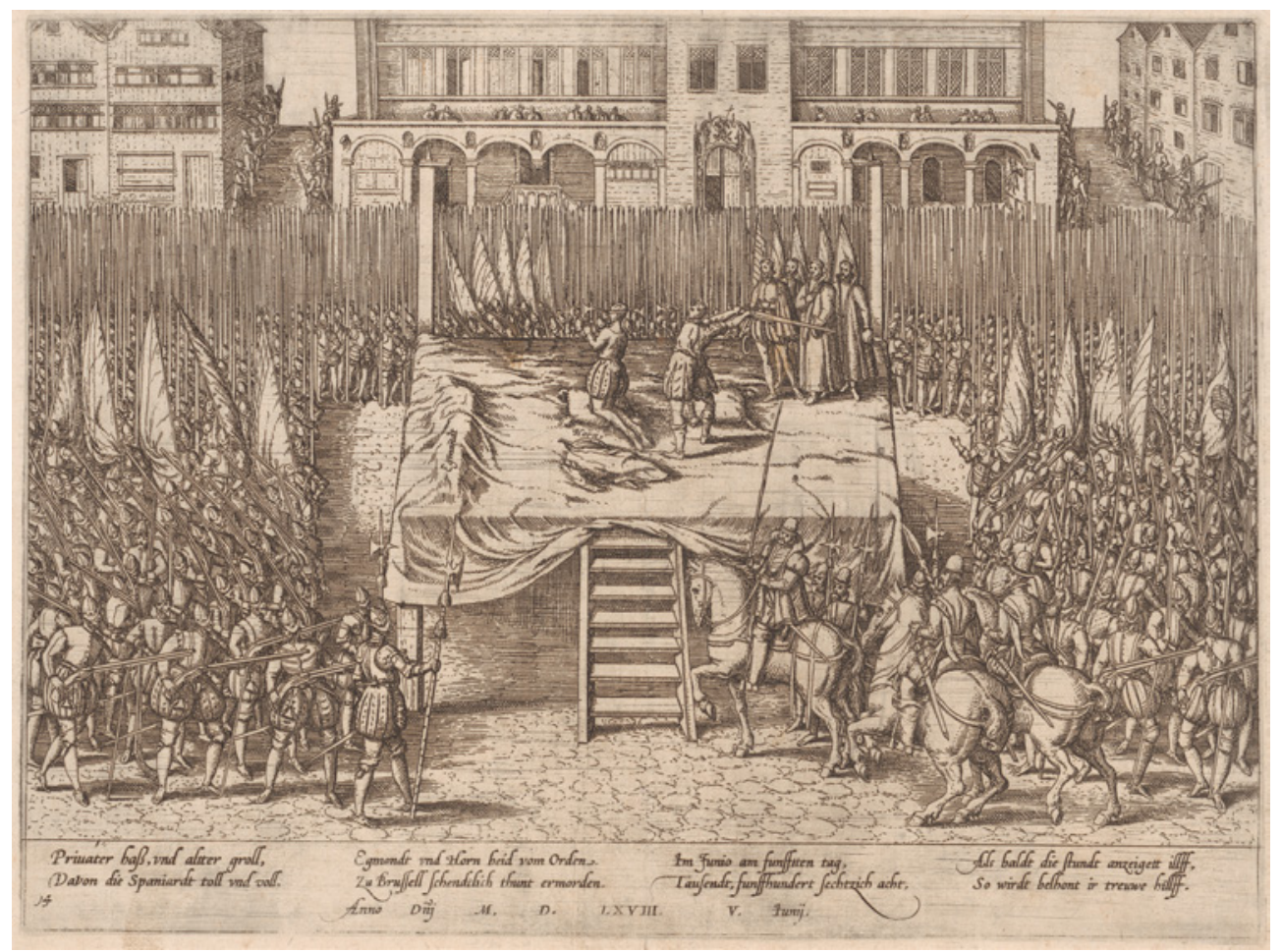

FIGURE 13.1 Frans Hogenberg, The Beheading of Egmond and Hoorn (ca. 1570), etching RIJKSMUSEUM AMSTERDAM RP-P-OB-78_463

count of Egmond, and Philippes de Montmorency, the count of Hoorn, both members of the Order of the Golden Fleece and descendants from the highest ranks of the nobility. ${ }^{30}$ They were executed in Brussels on the Grand Place on 5 June 1567.

The corresponding Hogenberg print shows the scaffold located at the centre of the sheet. The executioner swings a sword back to behead Hoorn who is kneeling blindfolded on a cushion. Egmond's dead body is already hidden under a cloth at the left margin of the place of execution. Dignitaries are standing at the right upper corner of the scaffold. The square in front of Brussels' town hall is not taken up by the usual bystanders, but by Spanish tercios, identified as mercenaries of Philipp II by flags bearing the Burgundian St Andrew's cross. Their pikes and arquebuses frame the execution scene. Soldiers even fill the streets leading to the square. The ubiquity of the mercenaries creates an overwhelming effect. The only civilian spectators in the scene are found on the

$30 \quad$ For the following see Voges, Das Auge der Geschichte, pp. 234-238. 
opposite side of the square above the arcades of the Brussels town hall, identified by the asymmetrical position of its tower.

The viewer watches the scene from a cavalier's perspective. He or she is positioned at the same height as the spectators standing on the town hall's balcony. This position creates the impression that the onlooker would watch the event from a window of one of the surrounding buildings. Yet the Brussels town hall faces the Maison du Roi. The building, commonly known as Broodhuis, served not only as the meeting place of several guilds but also housed the royal court. After Alba's mercenaries had brought Egmond and Hoorn to Brussels, they kept them imprisoned in that very building. The visual report positions its onlookers at the same spot where the grand seigneurs spent the last minutes of their lives before their execution. The beholder takes the place of the next convicts who would be led to the scaffold like Egmond and Hoorn. The free space in front of the wood structure contributes to the impression that it is the onlookers turn to ascend the scaffold next.

This integration of the audience is intensified by a rider on a horse who seems to look from the steps to the scaffold straight at the onlooker outside the picture. Hogenberg's visual report shows the rider as a viewer of the actual viewer. The onlooker is watched how he or she is watching the depicted occurrence. This eye contact positions the viewer as a part of the picture; the beholder is drawn right into the scene. The rider can be identified as Jan Grouwels, who was, because of his red wand of office, commonly known as Spell or Spelleken. ${ }^{31} \mathrm{He}$ was the provost of the marshal and thus concerned with administering justice. Many of Hogenberg's contemporaries disliked him for two reasons: he was considered to be cruel when prosecuting confessional dissidents and he had a reputation for arresting innocents in order to blackmail their families. In Hogenberg's print, Grouwel personifies a nefarious and ruthless officer of Alba, the 'Iron Duke'. In other words, the Hogenberg print expresses a situation of a twofold threat. On the one hand, Alba's mercenaries have replaced the citizens on the most important public space in Brussels. On the other hand, the visual report integrates the onlookers and threatens them with being the next to be executed.

The caption at the bottom of the sheet fosters this interpretation of the execution:

31 Alexandre Henne and Alphonse Wauters, Histoire de la ville de Bruxelles. Tome premier, der Ausgabe von 1845 (Bruselles: Culture et Civilisation, 1968), p. 418. 
Private hate and old grudge, Thereof the Spaniards are full, Egmond and Hoorn, both from the Order [of the Golden Fleece, Rv], Were murdered shamefully in Brussels, On June the fith day, Thousand, fivehundred and sixty eight, As soon was known, This is how their loyal help was rewarded. ${ }^{32}$

It asserts that the Spaniards were full of private hate and rancour. They dishonourably murdered the knights of the Order of the Golden Fleece, over whom Alba had no jurisdiction as they could normally only be judged by the chapter of the order. The caption suggests that Alba had not only illegally made an example of Egmond and Hoorn to warn the other members of the high nobility, but that he had also killed them out of personal dislike. While untrue, this argument was prevalent among Brussels burghers, as expressed, for instance, in the diary of Jan de Pottre. ${ }^{33}$

The modus operandi of ritual punishments like the public execution of Egmond and Hoorn aimed to reach a mutual agreement by violently excluding criminals from the body politic and by displaying this consent ostentatiously. Justice was not administered if no agreement between the authorities and their subjects could be reached. In this case, the punitive authorities appeared to be tyrannical because they offended the judicial fundament on which the political order relied.

The Hogenberg print exemplifies an extreme form of authority: autocratic rule in which every power broker is considered not a partner, but a rival for authority. Moreover, Hogenberg's depiction of the execution declares Egmond and Hoorn to be political martyrs. They died, the print insinuates, because they did not fight the Protestant movement vehemently enough, because they rebelled against the government by being moderate and by looking for compromise. This injustice falls back on Alba and his abetters. They have discredited themselves by their violent and tyrannical behaviour. With the execution of Egmond and Hoorn they show that the political system of mutual trust and reciprocal loyalty between sovereign and subjects has been violently abolished. The public beheading of Egmond and Hoorn was an attempt by Alba's regiment to re-establish the political order that had been disrupted by delinquents. Hogenberg transforms this demonstrative restoration of order into its

32 Geschichtsblätter, p. 118. All translations are my own, unless otherwise indicated. The end of a verse is indicated by comma.

33 Cf. Jan de Pottre, Dagboek, 1549-1602. Naer het oorspronkelyk handschrift in de Koninglyke Bibliothkeet te Brussel berustende, Maetschappy der Vlaemsche Bibliophilen (Ghent: C. Annoot-Braeckman, 1861), p. 3 o. 
inverse: in fact, it is Alba and his Spaniards, the judge and his executioners, who disturb the political order, not their victims.

\section{From Postestas to Violentia}

The prints showing the subsequent Spanish military achievements in the Low Countries follow the same line of argument. This is evident especially in the case of exemplary punishments that affected entire cities. On 2 October 1572, after Alba had pursued William of Orange, the figurehead of the nobility's revolt against Alba's regime, the Spanish troops arrived at Mechelen. ${ }^{34}$ A delegation of Mechelen's ruling elite welcomed the duke of Alba outside the city walls and submitted themselves in the name of the whole civil community. As the story goes, Alba ignored this sign of cooperation and decided to set yet another example: he allowed his troops to pillage the entire city, with the sole exception of the St. Rombouts Cathedral.

Two days later, he commissioned a broadsheet at the workshop of Christophe Plantin in Antwerp, justifying his course of action. ${ }^{35}$ Since somebody had shot at him, Alba had no choice but to proceed militarily with the utmost severity ('par toute rigeur'). Every other city that would resist his troops and his authority would suffer the same fate. At Alba's request, Plantin produced just 150 copies of that broadsheet in Dutch and 100 copies in French. ${ }^{36}$ In contrast to official announcements aiming at a public as broad as possible, Alba distributed the copies only among rebellious cities. That means the broadsheet not only justified Alba's sack of Mechelen: it also threatened all other civil communities and urged them to surrender to his rule. Initially his strategy was successful: the moment other cities heard that Mechelen was sacked, they sent delegations to Alba to capitulate in advance. Pillaging Mechelen and presenting its fate in print was just another form of exemplary punishment and therefore a convenient way of securing the recognition of his authority.

As in the case of Egmond and Hoorn, Hogenberg's workshop published a visual report of the sack, but this time shortly after the actual occurrence. The scenery can be divided into three sections. In the background, it shows how the Beggars under the Prinsen-flag are moving away from the city. In the middle ground, the beholder is looking at rows of houses, among them the

\footnotetext{
34 For the following see also Arnade, Beggars, Iconoclasts, and Civic Patriots, pp. 227-228.

35 Declaration des ivste causes du saccaigement de la ville de Malines ([Antwerp: Plantin]1572), USTC 4059 .

36 Stensland, Habsburg Communication, pp. 58-59.
} 


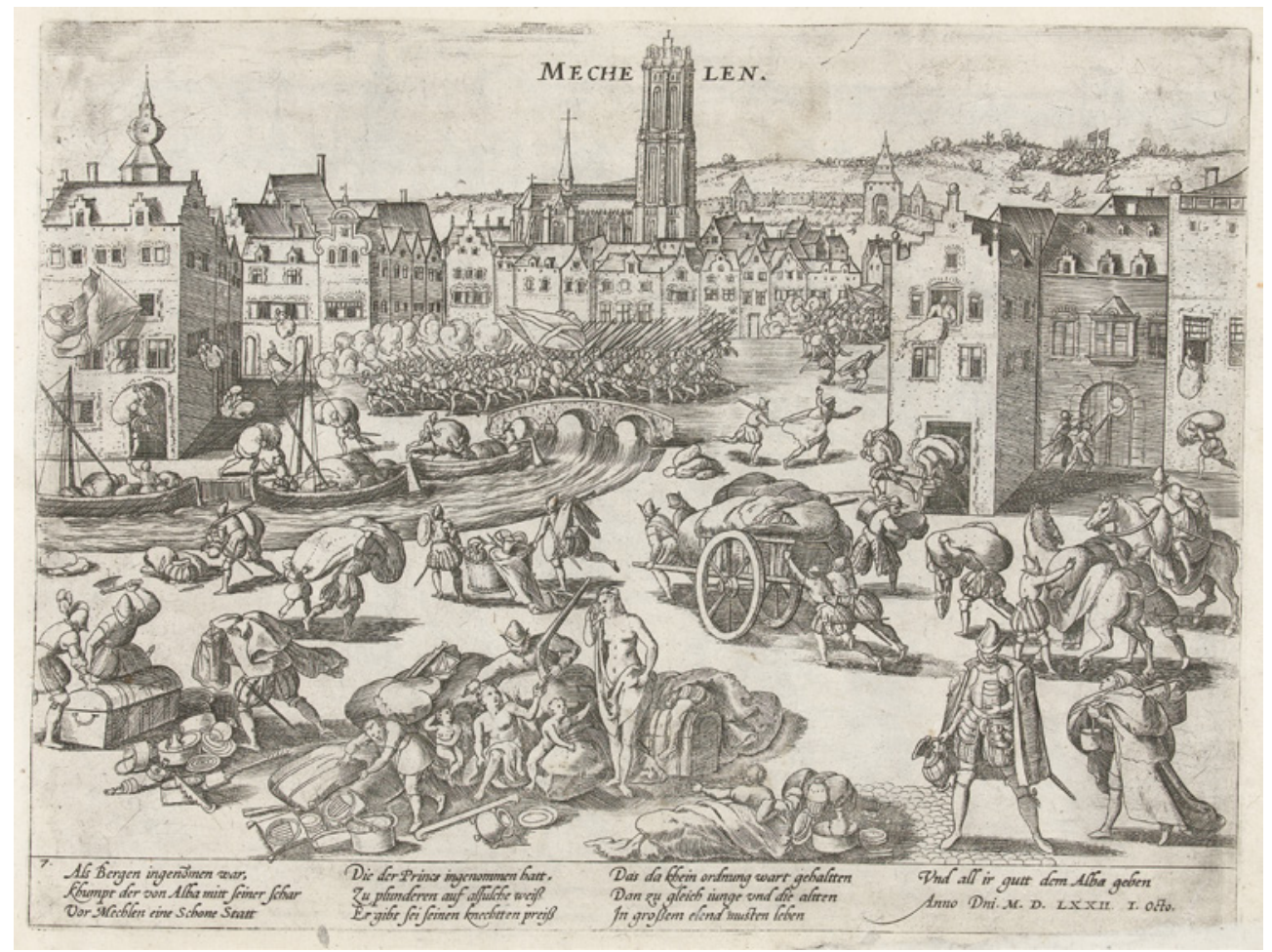

FIGURE 13.2 Frans Hogenberg, The Sack of Mechelen (ca. 1572), etching RIJKSMUSEUM AMSTERDAM RP-P-OB-78_784-115

St. Rombouts Cathedral standing out as a prominent landmark. Its tower is jutting into the written name of the city. At the same time, the buildings form the backdrop for the different actions the beholder can make out. First, Alba's soldiers invade the city and begin to shoot. Then, they cross a bridge and enter the houses. The visual report shows the seizure of Mechelen as a transgression of boundaries; the city is deprived of being an enclosed, walled-in shelter. In the foreground, finally, the print depicts the extent and consequences of the sack of the city. A group of women and children is located in its centre. Their nudity implies the sexual violence they had to endure. ${ }^{37}$ The position of the crying woman under the St. Rombouts Cathedral and the name of the city give the impression that the city is being personified. ${ }^{38}$ Here, the mode of

37 For other depictions of rape as metonomy for the Dutch Revolt consult Amanda Pipkin, Rape in the Republic, 1609-1725. Formulating Dutch Identity (Leiden/Boston: Brill, 2013).

38 For young women as personifications of cities see Thøfner, A Common Art, p. 55. For the complex interplay of bodies and allegorical personifications on stage: Sabine Schmitz, $\mathrm{La}$ 
representation changes from realism to allegory. The message of the scene in the foreground, however, is verified by the topographical details in the middle ground: the army of Flanders raped the city of Mechelen. ${ }^{39}$

The caption consists of ten verses and an additional line providing the date of the seizure. The verses inform the audience about the immediate past before Alba had come to Mechelen and summarise what his troops did once they arrived: first, Alba seized the city of Mons, but then turned to Mechelen as it was held by the Prince of Orange. He allowed his soldiers to sack the city. ${ }^{40}$ The caption locates the event in a temporal context and qualifies the deeds of Alba and the Army of Flanders as an overthrow of the civic polity.

The static picture creates temporality by showing different stages of the event in distinct spaces. As the eye of the beholder moves from one point to another, he or she gets the impression of watching an ongoing action. The spatial structure of the depicted city determines the temporal structure of the shown action. Additionally, the topographical details of the buildings offer a surplus that does not add anything to the narrative plot. For the actual sack visual details of the buildings are not important. However, this richness of details creates what Roland Barthes called a reality effect. ${ }^{41}$ They connote, in other words, a mimetic representation of Mechelen. It is a rhetorical means of creating the illusion of realism. ${ }^{42}$

The combination of the temporal structure, the detailed topography and clearly identifiable actors - and their victims - presents the sack of Mechelen like a scene of a stage play. ${ }^{43}$ In this case, the scene shows what is nowadays

Langue de Bruegel. Körper/Bilder als Chiffren Kultureller Identität im Französischsprachigen Theater der Spanischen Niederlande (Heidelberg: Universitätsverlag C. Winter, 2011).

39 On the topoi of the urbs capta see Arnade, Beggars, Iconoclasts and Civic Patriots, pp. 223224. For iconographic traditions see for instance Neil Cox and Mark Greengrass, 'Painting Power: Antoine Caron's Massacres of the Triumvirate', Past and Present supplement 7, 214 (2012), pp. 241-274; Suzanne Boorsch, 'The Massacre of the Innocents after Francesco Salviati by Giovanni Battista Cavalieri', Print Quarterly, 16 (1999), pp. 266-273; Philippe Rouillard, 'Marc-Antoine Raimondi. Les Massacres Des Innocents', Nouvelles de l'Estampe, 179-180 (2001), pp. 13-32.

40 For this and the following quotes see Geschichtsblätter, p. 137: "Young and old had to live in despair as they all had to give their belongings to Alba".

41 Roland Barthes, 'Der Wirklichkeitseffekt', in Das Rauschen der Sprache, Kritische Essays, $I V$ (Frankfurt am Main: Suhrkamp Verlag, 2012), pp. 164-172.

42 Cf. additionally Gérard Genette, Die Erzählung, ed. Jochen Vogt, trans. Andreas Knop, 3., rev. a. corr. ed. (Paderborn: Wilhelm Fink, 2010), p. 106.

43 For the importance of theaters and stage plays see Anne-Laure van Bruaene, 'Harmonie et honneur en jeu: Les compétitions dramatiques et symboliques entre les villes flamandes et brabançonnes aux quinzième et seizième siècles', in Marc Boone (ed.), Le verbe, l'image et les représentations de la société urbaine au Moyen Age. Actes du colloque 
called a 'massacre', a term coined in its modern sense in the second part of the sixteenth century. ${ }^{44}$ Just one year after the fleet of the Holy League had secured a dashing victory against the Ottoman forces near Lepanto and just some weeks after the St. Bartholomew's Day massacre in France, Hogenberg's visual report shows how a military inferiority was actually a moral superiority. His print gives its beholder the impression that he or she can watch with their own eyes the infamous actions of the Army of Flanders. At the same time, the visual rhetoric leaves no choice in which side to choose. The reality effect is therefore a subtle means of conveying a stereotyped image of Spanish soldiers. Hogenberg's visual report not only transferred the negative image of Alba to all mercenaries under Spanish command. It directly contradicts Alba's broadsheet and urges all other cities to close their gates in case Spanish soldiers are approaching.

Hogenberg's visual report about the sack of Mechelen was the first depiction of a massacre in the Low Countries. ${ }^{45}$ In the course of the conflict, many sacks by the Army of Flanders were to follow, each represented in a print by Hogenberg's Cologne workshop. ${ }^{46}$ Since Hogenberg omitted to represent how the rebels sacked cities, depicting massacres was a means of emotionally fostering the resistance against Spanish rule.

\section{Joyous Entry}

The Joyous Entry of Anjou as duke of Brabant was the first ritual entry of a new ruler into Antwerp since Philip II's 1549 grand tour. ${ }^{47}$ It was modelled on the huge spectacle of the solemn rituals dating back to the reign of the Dukes of Burgundy in the late Middle Ages. These rituals used different media: speeches, music, tableaux vivants, theatre plays, processions and triumphal arches, and pictures. By the time of Anjou's Joyous Entry, both the seat of the States General and the residence of William of Orange were located in Antwerp. Hans Vredeman de Vries, a well-known artist, who was not suspected

international tenu à Marche-en-Famenne du 24 au 27 Octobre 2001 (Antwerpen: Garant, 2002), pp. 227-238.

44 Cf. Ramon Voges, 'Macht, Massaker und Repräsentation. Darstellungen Asymmetrischer Gewalt in der Bildpublizistik Franz Hogenbergs', in Jörg Baberowski and Gabriele Metzler (eds.), Gewalträume. Soziale Ordnungen Im Ausnahmezustand (Frankfurt am Main: Campus Verlag, 2012), pp. 29-69.

45 On earlier depictions of massacre see also Voges, Das Auge der Geschichte, pp. 301-303.

46 Cf. e.g. Ramon Voges, 'Macht, Massaker und Repräsentation'.

47 Cf. Bruaene, 'Spectacle and Spin', pp. 268-274. 


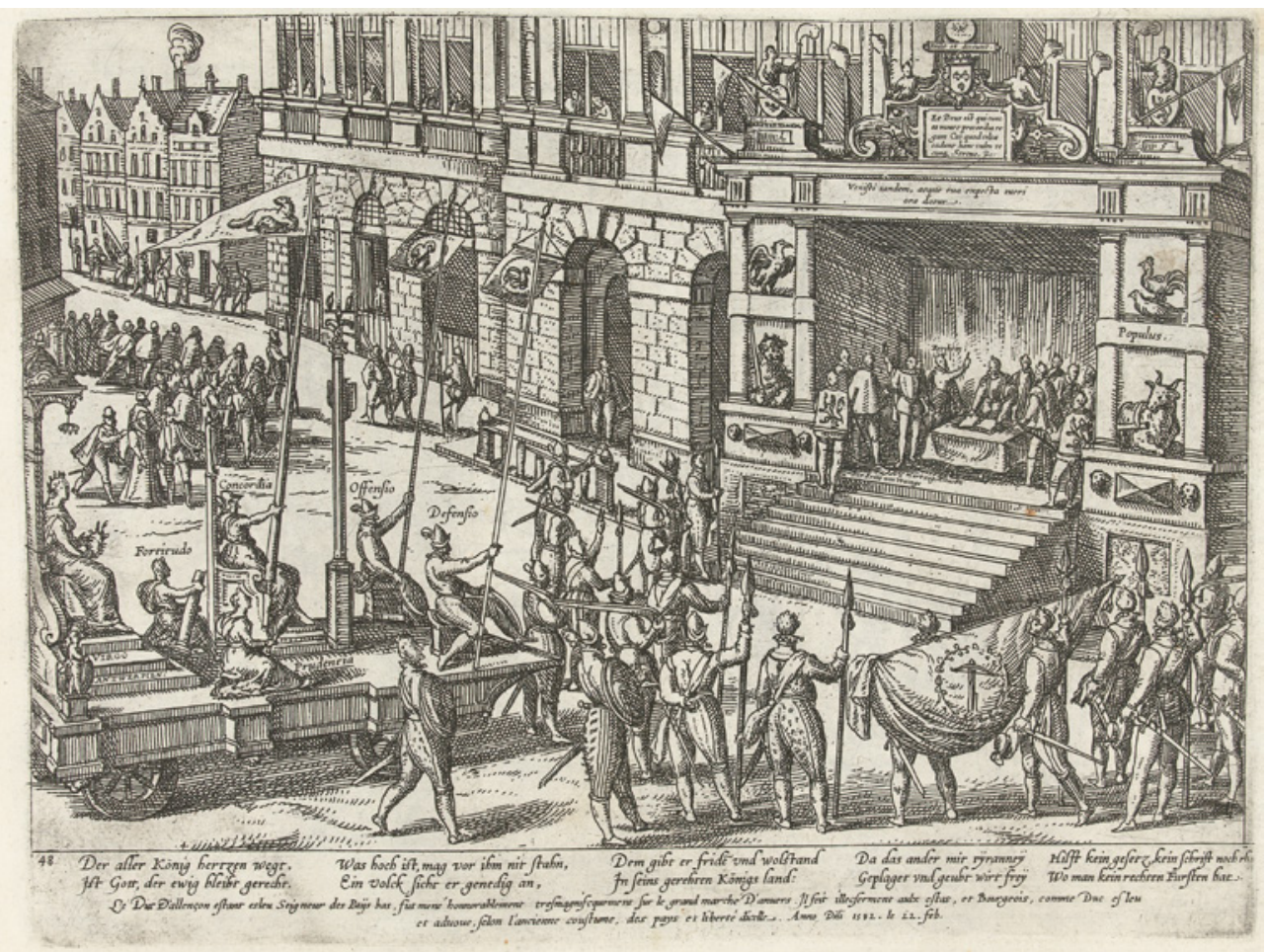

FIGURE 13.3 Frans Hogenberg, The Oath of Anjou (ca. 1582), etching

RIJKSMUSEUM AMSTERDAM RP-P-OB-78_784-205

of being a religious or political radical and who was responsible for the fortifications of the city, prepared and conducted the Joyous Entry. Petrus Loyseleur de Villiers, William of Orange's court chaplain and one of the principal authors of the prince's Apology, had written the official book of commemoration. ${ }^{48}$

48 For the commemoration book cf. Helen Mary Carmichael Purkis (ed.), La magnifique Entrée de François d'Anjou en la ville d'Anvers, facsimile reprint of the Antwerp edition from 1582 by Christopher Plantin, Renaissance Triumphs (Amsterdam: Theatrum Orbis Terrarum, 1976); for some cheaper and smaller reprints cf. De blijde ende heerlijcke incomste van mijn-heer Franssois van Vranckrijck, ... Hertogh van Brabant, van Anjou, Alensson, Berri, etc.in sijne zeer vermaerde Stadt van Antwerpen (Antwerpen: Christoffel Plantijn, 1582), UstC 401946; La ioyevse \& magnifique entrée de Monseigneur Françoys de France ... dvc de Brabant, d'Anjou, Alençon, Berri, \&cc. en sa tres-renommée ville d'Anvers (Antwerpen: Christoffel Plantijn, 1582), ustC 4129; cf. Karen L. Bowen and Dirk Imhof, Christopher Plantin and Engraved Book Illustrations in Sixteenth-Century Europe (Cambridge: Cambridge University Press, 2008) for an overview of the editions; for the Apology see esp. Martin van Gelderen, The Political Thought of the Dutch Revolt 1555-1590 (Cambridge: Cambridge University Press, 1992). 
On 22 February 1582, Anjou took an oath before the newly restored city hall of Antwerp to uphold every privilege and liberty mentioned in the so-called Blijde Inkomst charter of $1356 .{ }^{49}$ If he did not act according to them, he would have forfeited his right to rule. Like the print about the sack of Mechelen, Hogenberg had printed the corresponding visual report shortly after the event. ${ }^{50}$ The beholder looks from a perspective at the side of a stage, a tableau vivant and some spectators. In the middle of the picture, there are members of the civic militia, one of them holding up his hand in order to swear. In the background the façade of the restored city hall and another line of houses can be seen.

Hogenberg's picture shows several allegories and symbols that were utilised during the solemn ritual. The tableau vivant portrays the Maid of Antwerp as a personification of the city. The virtues fortitudo and prudentia are attributed to her. Concord sits enthroned behind offensio and defensio. She holds a pennant with wolf and lamb, the other two a pennant with pelican and with chick and hen. ${ }^{51}$ The Maid of Antwerp faces Anjou at eye level. His accession to power is represented as a marriage between city and ruler. The stage on which Anjou is taking his oath - in front of the civic community as well as William of Orange and the city magistrates - looks like a triumphal arch. In the relief on their left side an eagle and the leo belgicus symbolise Anjous power, on the right side a cockerel sitting on a hen stands for vigilance and an ox bearing a yoke symbolises obedience..$^{52}$ In the foreground, members of the newly installed civic militia are standing with their banner as if to underline the defensibility of Antwerp. ${ }^{53}$

In Hogenberg's visual report, Anjou is neither the absolute ruler nor a person to worship and admire, but a partner in a legal contract based on mutual acknowledgement. The confident burghers of Antwerp owe him obedience and fealty only inasmuch as he fulfills their expectations: Anjou has to uphold their documented rights and liberties. He has to defend them militarily and save the city from harm. He has to act not only prudently and boldly, but also

49 See Arnade, Beggars, Iconoclasts and Civic Patriots, pp. 311-318.

50 Geschichtsblätter, p. 233.

$5^{1} \quad$ For a contemporary description of the wagon cf. La ioyevse \& magnifique entrée, $36 \mathrm{f}$.; for the iconography cf. Frank Deisel, 'Der Löwe, Die Kuh, Der Garten und der Orangenbaum. Zur Politischen Ikonographie der Niederländischen Gesellschaft und des Hauses Oranien', in Horst Lademacher (ed.), Onder den Oranje Boom. Textband: Dynastie in der Republik. Das Haus Oranien-Nassau als Vermittler niederländischer Kultur in deutschen Territorien im 17. und 18. Jahrhundert (Munich: Hirmer, 1999), pp. 117-136.

$5^{2}$ The Latin inscriptions emphasise that Anjou was longed for and that God would prize these provinces that were given a just ruler, cf. again La ioyevse \& magnifique entrée, p. 51.

For the organisation of the militia cf. Thøfner, A Common Art, pp. $126 f$. 
selfless in the interest of the city. He has to solicit Antwerp's approval and win the burgher's favour. With his oath he expresses that he accepts these conditions, bearing witness in front of all the people present. Altogether they establish the new political order with Anjou at its top.

The print by Hogenberg dissolves the temporal and spatial boundaries of this ephemeral occurrence. It extends not only the range of the face-to-face medium Joyous Entry but also transcends the act of bearing witness among the people present. The print makes the occurrence permanent. In other words, Hogenberg's visual print puts more pressure on Anjou to live up to expectations. By showing how Anjou takes his oath, the beholder becomes a witness. As in the print about the execution of Egmond and Hoorn, the viewer takes part in the event, but this time he or she is establishing a new political order. Hogenberg's visual report adds and extends the original ephemeral face-to-face medium, and acts as its broker in bringing it to a far larger public.

Hermann Weinsberg, a Cologne burgher and long-time member of the city's magistrate, was one of the buyers of Hogenberg's prints. ${ }^{54}$ He kept a personal chronicle in which he noted family affairs as well as major political events. ${ }^{55}$ In one of his entries, he explains that on 23 March 1583 he had bought six prints made in Hogenberg's workshop for 12 Albus. ${ }^{56}$ Weinsberg's entry is not only revealing because it gives crucial information about prices: Hogenberg's visual prints were sold for the standard business prices for single broadsheets. ${ }^{57}$ It also reveals how a member of the urban elite of a Free Imperial city read Hogenberg's prints just one year after Anjou was inaugurated and took his oath in Antwerp. This moment is especially informative since, in the meantime, Anjou had become tired of the limitations of his authority and of the missing support from the northern provinces of the Low Countries. He had tried to seize power in Antwerp but his coup failed and he was driven out of the city. ${ }^{58}$ Shortly before Weinsberg bought the six Hogenberg prints, Anjou had left the Low Countries for good.

54 For Weinsberg see the collective volume edited by Manfred Groten (ed.), Hermann Weinsberg (1518-1597). Kölner Bürger Und Ratsherr. Studien zu Leben und Werk (Cologne: SH-Verl., 2005).

For Weinsberg's process of gathering news and taken note of them see Eva-Maria Schnurr, “Jedem anbringer gleub ich so bait nit". Informationsbeschaffung und Mediennutzung des Kölner Bürgers Hermann Weinsberg während des Kölner Kriegs (1582 bis 1590)', Geschichte in Köln, 56:1 (2009), pp. 171-206.

56 Manfred Groten (ed.), Gedenkboich. Liber Senectutis (Institut für geschichtliche Landeskunde der Rheinlande der Universität Bonn, n.d.), f. 396v-397r; for the prints cf. Geschichtsblätter, pp. 228, 231-233 and 237f.

57 See Duke, 'Posters, Pamphlets and Prints', p. 170.

$5^{8}$ Cf. for instance Hogenberg and Hogenberg, Geschichtsblätter, p 238. 
In his entry, Weinsberg gives a short report on what he had learned from the prints: First the burghers of Antwerp had paid homage to Anjou. But as he tried to take the metropolis by force, he was expelled from the city. Weinsberg was satisfied with this development. He interprets the Hogenberg prints in the sense of self-confident civic republicanism: 'These sheets warn everybody not to trust foreign princes and they show what burghers can achieve if they stand united and stick together in concord. ${ }^{59}$ This is an interpretation of the events by Weisenberg, a proud burgher and member of the civic magistrate of a Free Imperial City who refuses to tolerate any interference of foreign powers into the internal affairs of independent cities.

\section{Conclusion}

Hogenberg's visual reports played an important role in political communication during the Dutch Revolt. The prints informed politically interested contemporaries like Hermann Weinsberg about recent events and developments in the struggle for power and authority. I have covered two principal issues in this essay: how the Hogenberg prints subverted legitimate potestas into illegitimate violentia on the one hand, and how the protagonists tried to re-establish a peaceful and functional polity on the other.

The visual reports by Hogenberg's Cologne workshop not only represented other media, especially the ostentatious rituals, but they also reacted to them, for instance in the case of the printed account of the sack of Mechelen. They acted as a broker of these mostly ephemeral media and emphasised, criticised or even inverted their political messages. By showing the occurrences either as a play on a stage or by integrating the viewer in the depicted scene, they appealed to the feelings of the beholder. At the same time, the Hogenberg prints addressed widely shared attitudes and opinions, for example by stressing the point of view of a proud civic community or accusing Alba of judicial murder. Although the visual reports look like factual and realistic representations, they make clear which side to choose in the ongoing conflicts. Both as news agents and as conveyors of messages they exercised power themselves, fostering support for the Dutch Revolt. 